\title{
The Comparison Analysis of Compulsory Education Language Curriculum Standard between China and Britain
}

\author{
Li Xiao \\ Hexi University, Zhangye 734000, China
}

Keywords: Compulsory education; Mother tongue; Curriculum standard; Compare

\begin{abstract}
The vocabulary of English relative to character is simpler, easier to write and identify, learn the phonetic alphabet can still reading the new words, so no will to read and write in English curriculum standard request separately, but is decomposed to speaking, reading and writing the sections. Reading aim to identify the glyph knowledge, put forward to grasp words in writing for spelling, writing, grammar structure put forward specific requirements. Language knowledge teaching implementation in the process of the ability training also is the practice in speaking, reading and writing on language knowledge teaching, may be more conducive to the students in the use of language practice. This article through the comparative analysis, the curriculum standards for compulsory education of both Chinese and English speakers was studied.
\end{abstract}

\section{Introduction}

The rapid development of science and technology and extensive use of information technology in the world provide new opportunities for various countries with new development opportunities with unprecedented challenges. Facing these new opportunities and challenges, many developed countries are looking to education field, on the basis of the concept of "reconstruction", working on a full range of curriculum reform based on the curriculum standard. As the core of basic education, the reform of Chinese is one of the important measures to draw up the new language curriculum standard.

\section{The significance of mother tongue teaching}

Native language course is the core of basic education courses around the world, although the course construction and its paradigm are different, in the national basic education curriculum system, the language is in a leading position. Back to the past, the ancestors of all nationalities have their own language with their own unique ways of mother tongue education in the past age [1]. When modern times come, with the development of science and technology and the change of the public life of Chinese, still further, due to demands of the time to build emerging nation states, the main point of education began to transfer from the elite to mass education--countries have successively carried out preschool education, compulsory education and vocational education and other forms of modern education for citizens of the right age. Chinese curriculum standard is the minimum target to ensure the quality of Chinese education and commitment to excellence, striving to clearly define expected learning outcome, expounding learning contents, and the expected outcome should be observed [2]. Therefore, the standard is also the evaluation scale with publicity, achievability and evaluability. The curriculum reform should be based on the standard. 


\section{The comparison between Chinese and English native language curriculum standard of compulsory education}

(I) The native language curriculum standards of English compulsory education

In English teaching/ study syllabus of England and Wales, the former asserts four key stages of English curriculum, the first phase: $5 \sim 7$ years old, $1 \sim 2$ grade; the second phase: $7 \sim 11$ years old, $3 \sim 6$ grade; the third phase: $11 \sim 14$ years old, $7 \sim 9$ grade; the fourth phasw:14 16, $10 \sim 11$ grade. Outline of learning puts forward learning requests from "speaking and listening", "reading" and "writing", and each part raises requirements from the "scope", "main skills" and "standard English language learning". English discipline regulates 8 standards (with special performance level), describing the manifestation of learning levels respectively. Evaluate at the end of the stage one, two, three respectively[3].

(II) The Chinese curriculum standards of compulsory education in China

As the most significant content of curriculum standard, the curriculum objective refers to the definition and expression of what students should know and be able to do after a period of learning. As Compendium of Curriculum Reform of Fundamental Education (trial) pointed out: the national curriculum standard "should reflect the basic requirements of knowledge and skills, process and method, emotional attitude and values, and so on to students of different stages ". Generally, issued by competent administrative department for education of the country or region, curriculum standard actually reflects the national or regional authoritative and mandatory expectations of students learning outcome. Curriculum standard usually includes intrinsic connected standards, mainly including content stands (stipulate learning areas) and performance standards (stipulate the level students in a certain field should be reached) [4].

\section{The enlightenment of English native curriculum standards in compulsory education on Chinese teaching}

(I) Pursuing high quality of Chinese teaching level to adapt to times development and participate in international competition

Compulsory education, the qualified education facing to all school-age students, must pay attention to the pursuit of education equality: both of providing every citizen equal education opportunities, and equal education results (the overwhelming majority of people fully developed). However, as a dilemma, the unity of equality and excellence is hard to kill two birds with one stone. At the turn of the century, native language curriculum standards of some countries clearly put forward that the standard "is a commitment to excellence", and "it is a long-term commitment, not a momentary conceivement", "the significant sign of excellent trend of anti-educational 'mediocre trend' ", "a challenging" decision. British English curriculum standard explicitly put forward that let students master the necessary knowledge and skills to help them to widely participate in the field of economic competition, making them as citizens enjoying the dignity and life satisfaction[5].

(II) Cultivating responsible citizens and forming state concepts

Although native language curriculum standard of many countries do not list separately "ideological and moral education goals", we could not consider that they ignore the requirements about them. Some standards are explicitly put forward in prefaces-- language learning "can enrich people's mind, cultivate responsible citizens, forming collective consciousness ". In specific requirements of listening, speaking, reading and writing: "encourage students to make the imaginative witty response", "making personal feel to literature", "understand the meaning of the article, express their own original ideas" and "make characteristic expression", " listening and speaking confidently" (British standard) [6].

(III) Pay equal attention to the practical application of literary edifying and language and words

Providing detailed requirements on reading, appreciation and evaluation of literary works: interpretative and creative evaluation proves the understanding of literary works from different historical period and cultural perspective to read literary works. There is considerable reading 
quantity in national curriculum standard of Britain, France and Germany. Curriculum standards in the UK requires "let students read children's literature as much as possible", listing detailedly classic literary works to students in the third and fourth phases [7, 8].

\section{Conclusion}

In a word, because of the course standard is the mandatory regulation in a country or a region to students learning outcome, so essentially, it is the main and direct basis of course development and implementation. As the basis of textbook writing, teaching, assessment and examination proposition, national curriculum standard is the basis of the national management and evaluation of course. This paper focuses on the comparison of the compulsory education language curriculum standard of China and England, expecting that provides reference to Chinese teaching standards of compulsory education in China.

\section{Reference}

[1] Zhang Guobao. “One Outline and Three Fundamentals”: The Practice and Research of Class Chinese Course on the Perspective of Curriculum [J]. Jiangsu Education Research,2017,20(12):68-71.

[2]Yang Qinfen. Questions and Improvements of Chinese Curriculum Standards - the comparison of Chinese, American and Australian Curriculum Standards [J]. Journal of Tianjin Normal University(basic education edition),2016,14(04):58-62.

[3]Wang Yu. On the Efficient Path of Cultivating Primary School English Extracurricular Reading Interests[J]. Tourism Overview(the second half of the month), 2016, 26(08):238.

[4]Wang Zhiqiang. The Comparison and Curriculum Concept Interpretation of New and Old Versions of "Chinese Course Standard” [J]. Journal of Inner Mongolia normal university (education science edition), 2016, 21(04):88-90.

[5]Rong Weidong. The Enlightenment of Foreign Language Curriculum Standard on Chinese Course Construction [J]. Language Planning,2015,16(01):4-9.

[6]Zhao Chunhong. The Comparison and Enlightenment of Contemporary Chinese and American Foreign Language Curriculum Standard [J]. Contemporary Education Research and Teaching Practice, 2015, 15(09):62-63.

[7]Guo Haiping. The Comparison of Objectives and Content Standards Between China and Australia[J]. Journal of Teaching and Management, 2015,12(02):57-59.

[8] Huang Aihua, Fu Mengzhou. The Referential Significance of American Senior High School Native Language Course on Chinese Reform in China-taking English Course of Senior High School of Montverde Academy [J]. Journal of Hangzhou Normal University(Social Science Edition), 2014,22(05):131-136. 